\title{
US nuclear agency to consider defensive move
}

The powerful budget authority within Barack Obama's administration is considering the consequences of moving the US nuclearweapons complex from its traditional civilian home within the Department of Energy to the Department of Defense.

In an undated memo, the Office of Management and Budget has asked both departments to submit a report by 30 September 2009 outlining the pros and cons of transferring the \$9.1-billion National Nuclear Security Administration (NNSA) - a move that could happen as early as 2011. The quasi-independent agency oversees $\$ 6.3$ billion in activities at the five facilities and three national laboratories that are responsible for the design, creation and stewardship of nuclear weapons.

Although the agency has been attacked from many corners for its perceived inefficiencies and micromanaging style, congressional supporters of the weapons complex are worried about the potential move's consequences for the non-weapons science that goes on at facilities such as the Los Alamos National Laboratory in New Mexico.

Jude McCartin, a spokeswoman for Senator Jeff Bingaman (Democrat, New Mexico), says, "Senator Bingaman has very serious concerns about narrowing the mission down to just defence work and what that might do to the laboratories."

"People are sick to death of following silly bureaucratic rules."

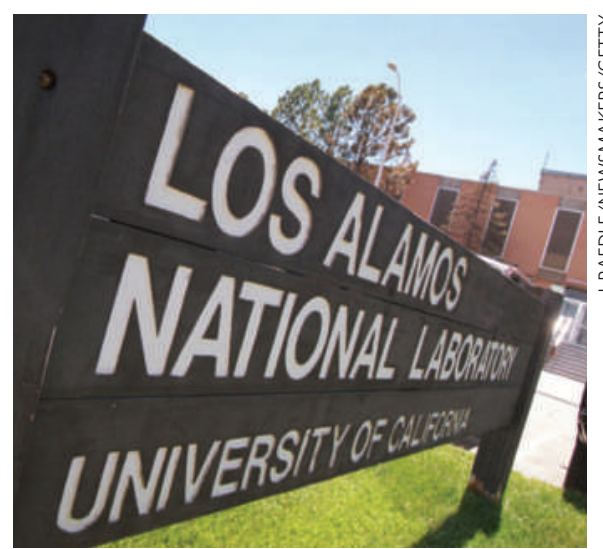

Non-weapons work at national labs could suffer.

Paul Robinson, former president of Sandia National Laboratories in New Mexico, says that the agency has become wasteful and excessively risk-averse. "The morale over these [nuclearweapons] missions is now near zero because people are sick to death [of] following these silly bureaucratic rules," he says. A spokesperson at the NNSA declined to comment.

In December 2006, a task force convened by the Defense Science Board recommended a different approach for managing the nuclear-weapons complex: dissolving the NNSA in favour of an entirely new organization - the National

Other defence-policy experts questioned the defence department's lack of experience with the large scientific facilities managed by some weapons labs, such as the National Ignition Facility, a laser-fusion experiment at the Lawrence Livermore National Laboratory in California. "The labs are 'big science' labs," says Clark Murdock, a senior adviser at the Center for Strategic and International Studies in Washington DC. And the defence department "has never done big science", he says.

By contrast, many in Congress, including Bingaman, are ready to reform the NNSA. It was set up in 1999 after the Wen Ho Lee security scandal at the Los Alamos lab exposed security and management issues at the energy department. A year later, a congressional oversight panel found the agency to be nothing more than a "paper organization, bereft of the leadership, structure, and degree of semi-autonomy intended by the Congress."
Nuclear Weapons Agency - that would report directly to the president. Murdock says such an agency could pursue its nuclear-weapons mission while the labs receive separate science funding streams from the departments of defence, energy and homeland security.

Any changes are likely to face stiff bureauEnergy was created in 1977 from the remains of the Atomic Energy Commission, the administration of Ronald Reagan in the 1980s tried and failed to shift the weapons complex to the defence department. Now, the incoming Energy Secretary, physicist Steven Chu, seems ready for the next showdown. On 22 January, Chu addressed all Department of Energy employees and was asked what role he saw for the NNSA. "It's going to remain a part of the Department of Energy, how's that?" he replied.

Eric Hand cratic resistance. After the Department of in a video transmission from Washington DC, 